\title{
Memory in Post-Conflict Societies: From Contention to Integration?
}

Cillian McGrattan and Stephen Hopkins

Collective memory, broadly conceived, has long been held to be an essential component within ethno-national belonging. For example, as Anthony Smith explains, a sense of historical continuity and common heritage is essential to some form of group cohesion and identification (1991). The idea that memory is intrinsic to processes of binding, bonding and 'othering' has been the subject of research across a number of disciplines. Often this work focuses, implicitly or explicitly, on the conflictual and divisive processes that memory mobilization triggers. Abdelal et. al. (2006), for instance, describe how identity consists of content and contestation meanings are broadly shared about identity, what it does, what it looks like and why it is important within groups; but those meanings can often be subject to differences of emphasis and interpretation. Given this fluidity, particular aspects of group belonging and identification become salient when they are triggered by changing circumstances (Chandra, 2006). As John Gillis points out, 'we are constantly revising our memories to suit our current identities'. As such, memory and national identity are congruent and symbiotic: 'Memories help us make sense of the world we live in', he goes on to argue, "memory work" is, like any other kind of physical or mental labour, embedded in complex class, gender and power relations that determine what is remembered (or forgotten), by whom, and for what end (1994, p. 3). 
Yet, in each instance of the politicization or mobilization of identity an act of depoliticization occurs - other elements, other memories, other experiences are muted, displaced or deferred. In each instance of contestation, an act of what Michael Freeden (1996) (in specific relation to ideology) calls decontestation can be glimpsed - in other words, the very meanings that attach to identities (for example, the interpretations given to purportedly critical historical events) are overwritten and overdetermined so as to elide difference and distinction in such a way as to offset or pivot away from conflictual readings. As Graff-McRae points out in her article in this Special Section, often, this glimpse takes place at oblique angles because the act of depoliticization or decontestation depends on silencing or 'ghosting'. The countermemories of non-dominant groups (in Graff-McRae's paper, for instance, gendered experiences of the Northern Irish Troubles) may be forgotten, ignored or pushed aside when they are not easily assimilated into the overarching group-understanding.

This special section draws together papers by Rebecca Graff-McRae and Adrian Little and Mark Macmillan that seek to problematize critical and under-studied aspects of these notions; the overarching idea is to explore the roles that memory may play in overcoming division. It is also the case, however, that memory work has the potential, particularly in societies attempting to grapple with long-standing and deep-rooted ethno-national identities, to be used by protagonists to perpetuate or accentuate such conflict, rather than ameliorate it. 
The rationale echoes that of Ed Cairns and Michael Roe, who argued that it is important to study the relationship between memories and conflict in helping to resolve conflicts'. They went on to explain that often 'groups are ... left with a sense of "victimhood" that stems from unacknowledged and unreconciled historic losses. These in turn present a powerful barrier to traditional methods of peacemaking and diplomacy and create new senses of wrong and injustice thus creating the potential for future conflict' (2003, pp.4-5). Cairns and Roe point to the fact that within transitions from conflict to peace, memory intersects with democracy in ways that do not always produce stability. The relationship is, of course, ambiguous because no guidelines exist (or are possible) to facilitate a deepening of democracy through memory work. Frequently, the problem faced in such societies is to balance building stable futures with instituting justice for historic grievances. This dilemma is compounded by the fact that often, in such societies, the language of peace, reconciliation, justice, apology, inclusion, and pluralism is itself filtered through ethnic understandings. The unintended consequence of peace-building policy then may involve issues of growing social fragmentation, increased insecurity, instability and political polarization. As Adrian Little and Mark McMillan argue in their article in this Special Section, it is also the case that researchers need to be aware of contemporary sources of grievance when they focus upon collective memories of ongoing historical conflict.

\section{Memory, Identity and Reconciliation}

If memory and memory work then are inherently conflictual, the possibility of using them as foundations for a stable, lasting and peaceful settlement seems misguided. The point has, perhaps, most famously been elucidated by Max Weber in his 
discussion of leadership and how Germany would rebuild from the First World War and the internal convulsions that coincided with its conclusion. Weber argued that raking over the causes of the war would be 'politically sterile'; it is part of a false ethic, he argued, of guilt in which social and political responsibility is inverted and focused on the past. The ethic is, essentially, populist and demagogic - it is easy prey for political leaders whose attractiveness lies in their ability to stir emotions rather than reason. For Weber, however, politics depended upon both: 'Politics is a strong and slow boring of hard boards. It takes both passion and perspective' (N.D. [1919]). His essay concludes with minor-key reflections on the 'Weltanschauungs politicians' who espouse what he sees as a kind of bad faith in politics - in other words, a criticism of politics without clear alternatives. The obfuscation of responsibility, as he sees it, diverts attention from where the focus ought to be - namely, on building a functional society out of the aftermath of war.

Steve Stern alludes to Weber's discussion at the beginning of his exhaustive dissection of memory politics in Chile. He frames the choice, between focussing on the past or instead on the future, as a 'Faustian bargain'; but he goes on to suggest that mortgaging the past for the sake of the future is perhaps an overly simplistic way of conceptualizing and describing how societies move beyond violence (Stern, 2004, p. xxvii). Instead, memory construction may be seen not simply as a battle between remembering/remembrance and forgetting; but rather as a very political process involving contestations over meaning, articulation and inscription. Frequently, it involves coming to terms with events that have some kind of inarticulate, traumatic resonance; events which provoke struggles over ownership, authorisation and, 
ultimately, political (de)legitimacy. There are also critical questions concerning the inter-generational cultural transmission of such memories, which may be mobilized in renewed conflict. This is, perhaps, to be expected: images of the past are key repositories of political authority in the present and are easily harnessed to legitimize contemporary political order(s) (Connerton, 1991, p. 3). Similarly, moments of transition often create an opening of political opportunities where 'the struggle [over memory] plays out between a variety of actors who claim recognition and legitimacy of their voices and demands. The memories of the oppressed and marginalised and the memories about oppression and repression ... emerge, usually with a double intent, that of asserting the "true" version of history based on their memories, and that of demanding justice' (Jelin, 2003, p. 29).

This paper explores some of the ways in which the in-group or intra-bloc competition over memory and remembrance, which constitutes so much of the dynamics of ethnonaionalist politics, reveals the limitations of Weber's problematic. In other words, while memory-work does occur at the national level it also constitutes much of what goes on at a lower, group-based level. (Although this is hinted at within Weber's paper - hence his despair over the emergence of a political culture dedicated to cynicism and emotionalism - his primary emphasis is to do with the frameworks of administration and political leadership that can emerge from transitions.) Memory 'wars' occur between ostensibly antagonistic ethnic communities over the distribution of state resources and the achieving of national and international recognition (Kubal, 2010; McGrattan 2012). A somewhat under-researched area relates to the issue of 
how memory battles also occur within communal groups and within ethno-nationalist blocs.

This dual-level perspective acts as a useful heuristic device for explaining developments in the Northern Irish case where long-term processes of both outbidding and underbidding have occurred. On the one hand, this has seen the moderate, middle class, small-c conservative and Catholic-dominated, 'constitutional' nationalist party, the Social Democratic and Labour Party (SDLP) being electorally overtaken by Sinn Féin (SF) - a party once aligned to the Irish Republican Army and dedicated to the violent overthrow of the constitutional status quo (Murray and Tonge, 2005). On the other hand, the moderate, middle-class, small-c conservative and establishmentProtestant Ulster Unionist Party (UUP) has been electorally overtaken by the Democratic Unionist Party (DUP) - a more radical, evangelical-based, ultraconservative alternative. Yet, as Henry Patterson points out, this has not happened simply because of intra-bloc outbidding; in fact, SF and the DUP can be seen to have moderated their stances in tandem with the strategic decision by the British and Irish states to remove overt political sponsorship of ethno-national blocs during the peace process, in effect delegitimising sectarian ideologies (2007, pp. 343-44). As such, while both the nationalist and unionist electorates have increasingly opted to vote for ethnic tribune parties, a degree of underbidding is also occurring within each bloc. At this intra-bloc level, a retrenchment of conservative and even moderate politics occurs as the two main unionist and nationalist parties - the DUP and SF respectively - seek to colonize the political space that was once the preserve of more 'moderate' parties 
such as the SDLP on the Catholic-nationalist 'side' and the UUP, which has been mainly supported by Protestant-unionist voters.

Although it is perhaps not as immediately apparent, a degree of underbidding is also discernible (and logically necessary) at the inter-bloc level. For example, this has been observed in the DUP's purported targeting of conservative, traditional Catholic voters through their hard-line stances against abortion and gay marriage (Tonge et al, 2015), and through SF's attempts at unionist 'outreach' by speaking of a willingness to hold 'uncomfortable conversations' about the past (Hopkins, 2015; McGrattan, 2016). While there may not be many immediate returns in terms of electoral capital in such activity - even under PR-STV vote transfers across the ethno-religious divide are minimal - a certain amount of political cache may reside in offsetting fears and suspicions among out-bloc voters. In effect, a delicate balancing act may be discerned: on the one hand, the maintenance of a relatively stable political culture is fostered through commemorative and symbolically salient work that focuses on inbloc sentiments and ideological tropes; on the other hand, more accommodative, open or even liberal positions are advocated to appeal to moderate supporters and to give the appearance of recognition of the beliefs of the 'other' ethno-nationalist bloc. This balancing act is logical in an era where the demographic gap between the Catholic minority and Protestant majority is increasingly marginal. ${ }^{1}$ In other words, despite apparent mutual antipathy, it is in the interests of politicians from both ethno-religious blocs to 'keep the ball in play' and maintain a semblance of political functionality. And it is this imperative - namely, a dynamic driven by aims that are almost taboo 
because to articulate them publicly would be to endanger the goodwill or wilful blindness upon which their political capital rests - that shapes intra-bloc competition.

Our claim is, thus twofold: not only does intra-bloc competition remain an underappreciated facet of the dynamics of transition in ethnically divided societies; but, secondly, that it can give rise to the appearance of democratic vitality and debate. Our argument is that it establishes the parameters for that debate, in effect, giving meaning to otherwise contestable and decontested concepts. Thus, the very framing of potentially contentious events, issues or problems is implicitly linked to a kind of 'policing' mentality that denotes the limitations of what is sayable or thinkable and the boundaries beyond which the unsayable lies.

\section{Intra-Bloc Memory Competition}

Viewing in-group or intra-bloc dissensus as framed by or set within the parameters of between-group relations, then, means paying close attention to the changing salience and meanings of concepts that are core to the group's ideological and normative coherence. When ethno-nationalist groups are making a transition from violent conflict to a more peaceful and democratic environment, reconciliation may be one such concept, implying as it does a settlement and a settled view of self but also a journey and something open-ended (Schaap, 2005). The concept is operationalized by being understood as a kind of direct object - in other words, reconciliation is an endpoint or an outcome of a political process. Alternatively, it can be understood as a verb - something that is done, a set of actions with an uncertain outcome (McGrattan, 
2015). Reconciliation also has a policing function: for reconciliation to occur, particular memories or ideas about the past are rendered taboo - a kind of unacknowledged 'pact of forgetting' in which the more sectarian and violent tropes are left aside or 'forgotten' for the sake of contemporary group or societal cohesion (Rieff, 2011). The languages and vocabulary of 'peace' and 'reconciliation' may, in this way, mask continuing antagonism. As Stef Jansen has pointed out in work on Serbian and Croatian remembrance and memory cultivation, claims-making based on the past does not necessarily need to involve the construction of new memories or the revision or airbrushing of historical 'facts'; rather, it proceeds in an ambiguous, negotiated and nuanced fashion based on vagueness regarding context and chronology and selectivity in recall and forgetting. Importantly, he argues, those dynamics are not simply the product of elite mobilization but may be an effort at an everyday level to abrogate responsibility: 'Not being too precise was considered wise: since vagueness allowed for generalised accusations, it protected the speaker from potentially nasty probing questions about individual responsibility and knowledge and it prevented speaking up about issues bringing one into a socially sensitive position. Vagueness, therefore, was a crucial instrument of self-protection' (2002, pp. 84-85).

Paradoxically, Jelin has identified these dynamics within the construction of ethnicized memory as being predicated on a sentiment or a belief in timeliness. That is, the content of memories being constructed is contained and shaped by a clearly set and unchanging conception of past, present, and future. In such a view, there is no room for diversity in the conception of time itself. Notions of time thus appear to stay outside the social frameworks and the actual processes of "framing" memories' (2003, 
p.13). Duncan Bell makes a similar point when he argues that the effect of nationalist memory-making is to act as a 'story that simplifies, dramatizes and selectively narrates the story of a nation's past and its place in the world, its historical eschatology: a story that elucidates its contemporary meaning through (re)constructing the past' (2003, p. 75). In short, if memory acts as a way of deferring or delimiting responsibility in time and space, it also acts as a way of constraining the range of responses deemed appropriate or possible. The process of selecting what to 'remember' and what to 'forget' is itself intensely politicised. We should also be mindful of Assmann and Shortt's injunction that it is not possible to neatly separate 'remembering' and 'forgetting'; every act of remembrance is at once an act of forgetting, because it is both selective and partial (2011, p. 5). These restricting and restrictive characteristics of nationalist memory-making work to reify the ways in which people and groups articulate their identities and can quickly become exclusionary of alternative historic experiences (based on ethnic-otherness or gender, class, age or locale) and grievance-promoting. In her article, Rebecca Graff-McRae explicitly argues that a critical feminist lens may 'complicate exclusive and exclusionary discourses centred on ethno-nationalist opposition with an acknowledgement of the political possibilities inherent in "other" memories, and memories of others.'

Graff-McRae's emphasis works to complicate the relationship between politics, history and memory. This is a point that is detailed in her (2010) book on the commemoration of the 1916 Easter Rising in contemporary Ireland. The coincidence of 1916 commemorations with those of the 1981 hunger strikes (that saw 10 Irish 
republican prisoners starve to death in the Maze/Long Kesh gaol in Northern Ireland) in 2006 gave rise to a problematic set of fissures and disruptions that troubled republican memory work and republican peace process politicking. On the one hand, republicans were able to capitalize on the conjunction as one understanding of the hunger strikes fitted easily into the accepted (nationalist) reading that 1916 was about martyrdom and blood sacrifice redeemed through nationhood. This is what GraffMcRae calls the 'progressive reading': the 1981 Hunger Strike is represented not only as a staging post en route towards the peace process, a watershed, but as the embodiment or epitome of both the true nature of the conflict (struggle) and republican attempts to overcome that conflict (2010, p.167). In other words, a historic continuity can be discerned once it is accepted that the republican story has always been about contending with outside (imperial) forces, but that through a series of sacrifices the movement has come into an ascendency. On the other hand, however, the coincidence of these commemorative anniversaries was also deeply destabilising for the mainstream republican movement's claims of continuity. This was due largely to the fact that what had been a pristine memory of heroic sacrifice, had become highly complicated, in two related ways. First, some republicans increasingly questioned whether the political compromises engaged in by their leadership, in the shape of the Good Friday agreement and its aftermath, could justify the heroism of so many of their fallen comrades (McIntyre, 2008). But, second, an erstwhile Provisional republican (O'Rawe, 2005; 2010), and member of the jail leadership during the Hunger Strike, had made the incendiary allegation that the leadership group outside the jail had deliberately scuppered the chances of a deal with the British government to bring the protest to an honourable close (after the deaths of 4 hunger strikers, but before the deaths of 6 others between July and October 1981). Such an allegation had 
the effect of throwing the established master narrative of republican memory into turmoil and doubt, highlighting the 'inherent instability of republican attempts to ground profound change in the imagined permanence of the past.' (Graff-McRae, 2010, p. 59). Although memory work often functions as an intra-community unifier, this particular case shows the potential for such collective engagement with the past to act as a focus for virulent contestation within the political community (Hopkins, 2014; 2016).

Geoffrey Cubbit contrasts social memory with collective memory, arguing that the latter is a 'species of ideological fiction' that is generated by the former, which is 'a set of processes ...that within any community are likely to generate a diversity of understandings both of what pasts ought to be evoked or described or celebrated, and of the particular contents that representations or evocations of each of these pasts should incorporate or articulate (2007, p.18). As Cubbit makes clear, what is 'social' about 'social memory' may mean something different depending upon which social group one belongs to or identifies with. Again, following Jelin, the implication can be extended towards distinctions in intra-group memorialization. As Omar Encarnación illustrates in his history of memory following the Spanish Transition, the left's desire to pursue justice towards the Franco regime was tempered by a number of factors including the fear of a return to civil war, the failure of the left to challenge Franco and internecine ideological struggles. European integration offered the left a means of redeeming these traumas, Encarnación argues: 'once it reached power in 1982, forgetting provided a useful political framework for the PSOE [the Spanish Socialist 
Workers' Party] to obscure its own history of political radicalism and to re-imagine Spain as a modern, European society' (2014, p. 77).

Encarnación is particularly sceptical of the ability of information recovery processes or truth and reconciliation commissions to facilitate overarching conciliatory readings and understandings of the past. The Spanish case, in effect, he argues, demonstrates that an (unspoken) agreement to avoid making political capital out of historic differences or the memories of those differences in the present is perhaps the most optimal way of avoiding what concerned Weber - namely, a counterproductive rerunning of historical battles in contemporary society. A complementary perspective is found in the work of Jelena Obradović-Wochnik who explores how the increasing prevalence of truth recovery processes in ethnically divided societies such as the Former Yugoslavia, upon which she concentrates, can have deleterious, silencing effects, which reinforce power disparities associated with ethno-nationalist group dynamics. Although this information retrieval work 'still carries a strong focus on silence-breaking activities', the framing and focusing of much of that work through the lens of ethno-national groupism may exacerbate the marginality of particular groups and segments of society. 'Selective academic engagement', occurs she argues, by the prioritization of 'activists' voices' (2013, p.334), thereby privileging certain types of stories and reproducing power dynamics that are founded on self-serving political narratives about the past: 'transitional justice practitioners, concerned with public participation, often fail to consider the context that makes such participation and speaking (im)possible' (p.330). 
Obradović-Wochnik's work discusses several ways in which such silencing practices occur including the allocation of collective blame, the construction of an imaginary, simplified 'public' audience, or the ethnicization of social groups or entire populations. She concludes, however, that transitional justice practices can nevertheless be reformed to ameliorate the tendency towards silencing by focusing on the exposure of the 'mechanisms that exclude' and the revelation of the 'complexities inherent within silences' $(2013$, p.347). The danger, of course, is that attempts to rebalance the deficit may create further regimes of exclusion. The problem may become exacerbated when placed within the context of deeply divided societies where the character of the state and the very nature of the social are often contested. In that type of situation the need to police in-group behaviour and discourse may be critical to electoral and political success. Memory and history, however, may not be completely malleable and may counteract attempts at direct manipulation of the historical record.

As Marc Augé points out, forgetting is essential for any society or even individual to function. Further, he argues, it is forgetting that shapes memory: 'Memories are crafted by oblivion as the outlines of the shore are created by the sea' $(2004$, p. 20). In other words, forgetting/oblivion and remembrance/memory are two sides of the one coin - it is deferral, or the consigning of the past to a depoliticised realm that is the real antagonist of collective and individual memory. Depoliticisation and decontestation of memory is, therefore, not solely associated with forgetting although the distortion of the past within nationalist remembrance may involve a degree of wilful blindness and willed amnesia (Judt, 2005). Rather, following Augé, it 
may be more helpful to view the manipulation of memory as concerning the muting of or removal of validity from alternative points of view to those held by cultural, political or governing elites. It is for this reason that Augé (following Paul Ricoeur, 1999) speaks of a 'duty of memory' based on vigilance and remembrance:

Vigilance is the actualisation of remembrance, the effort to imagine in the present what might resemble the past, or better (but only the survivors could do it and their numbers are decreasing every day), to remember the past as a present, to return to it to find the hideous shape of the unspeakable again in the banalities of ordinary mediocrity $(2004$, p. 88$)$.

For Augé, this duty of memory works to balance the Weberian duty to forget and move forward. Individual and counter-memory and what might be termed the historical record (primary, archival sources, autobiographies and oral history archives), however, provide impediments to the manipulation of the past. As Michael Schudson has argued, the past is not completely malleable: 'Yes, individuals and groups try to co-opt memory for their own purposes; but no, they do not do so with a free hand so long as success in even convincing oneself requires non-contradiction by others' (1989, p. 112). In other words, silencing, forgetting and deferral are limited by counter-memory and, as Jacques Derrida points out the 'deafening consensus' that they create in insisting on particularistic memories or narratives about the past simply 'arouses a suspicion ... [and] awakens us where it would like to put us to sleep' (1994, p.97). 


\section{Memory and the Past in Northern Ireland}

As pointed out above, the imperative for cultivating intra-bloc cohesion around specific narratives about the past and the fencing-off of alternative readings as almost taboo is shaped and constrained by broad and perhaps under-acknowledged inter-bloc dynamics. To be sure, in Northern Ireland this balance is precarious and negotiated and frequently politicians and the media attached to each ethno-national bloc are repelled by the commemoration culture of their erstwhile ethnic opponents. This may occur despite the best of intentions that commemoration should be open and inclusive. For example, Northern Irish unionist parties refused to send representatives to the 1916 Easter Rising centenary commemorations in Dublin, contending that the events were geared towards celebrating a violent republican ideology that they opposed; as a spokesperson for the DUP argued: 'The events of that failed rebellion should be studied, not celebrated. The legacy of 1916 is a poisonous one as it served to enshrine the notion that armed republican groups, no matter how small or deranged, can kill and maim for Ireland' (Newsletter, 2016). The Janus-faced nature of commemoration in terms of providing for both outbidding and underbidding can be seen in the aims drawn up by the group of historians who were appointed to advise the Taoiseach (the Irish premier) on the so-called decade of commemoration in which the Easter Rising events marked a centre-piece: 'Official events', they argued, 'must within reason be inclusive and non-partisan, but the State should not be expected to be neutral about its own existence. The aim should be to broaden sympathies, without having to abandon loyalties, and in particular recognising the value of ideals and sacrifices, including their cost' (Decade of Centenaries, N.D.). In other words, history can only go so far in 
facilitating reconciliation and the remembrance of the beliefs of foundational figures may result in a kind of commemoration that unsettles more liberal values in the present.

Since the signing of the Belfast/Good Friday Agreement of 1998, there have been several concerted attempts to overcome these types of tensions that arise from oppositional ideologies and historical perspectives. That Agreement was itself an exercise in political constraint and represented the culmination of a lengthy process of negotiation between the main political leaders in Northern Ireland and the two governments in London and Dublin, which was chaired by Senator George Mitchell. The Agreement itself set out an elaborate institutional framework that would provide devolution for Northern Ireland; cross-border cooperation on a consultative basis; and fora for discussing issues pertaining to the British Isles as a whole. It also included provisions for the reform of policing, the early release of paramilitary prisoners and the decommissioning of paramilitary weapons and the demilitarization of Northern Ireland.

The latter issues were to bedevil the implementation of that framework until 2007 when the two main nationalist and unionist parties, SF and the DUP agreed to share power and the British government agreed to devolve responsibility for policing and justice to the Northern Irish Assembly. Arguably, since 2007 what have become known as 'legacy issues' pertaining to victims' rights, the possibility of a truth and reconciliation process and public symbolism surrounding the flying of flags and 
parades have dominated political debate. The first detailed consultation exercise on dealing with the past was carried out by the Consultative Group on the Past in Northern Ireland (CGPNI) in 2008-2009. CGPNI was a body established by the then Labour government and comprised mainly church leaders and civil society spokespersons. Its key proposal of a legacy commission to deal with outstanding issues relating to truth recovery and victims' needs and rights was, however, overshadowed by its call to award a $£ 12,000$ compensation payment to the relatives of all the bereaved - a kind of blanket payment that did not discriminate between bystanders, innocent victims and individuals killed while carrying out operations on behalf of paramilitary organizations.

Since then there have been two further attempts to provide a roadmap for moving what might be called the politics of the past off the centre stage. Firstly, in the autumn of 2013 Dr Richard Haass and Professor Meghan O'Sullivan chaired a series of consultations and negotiations with Northern Irish politicians. Their detailed report separated truth recovery or storytelling approaches to the past from the more forensic work of the police and judiciary. News reports suggested that the Northern Ireland parties were largely in agreement about dealing with the past but remained divided on public symbolism. The following year, Northern Irish politicians were again brought into a talks process, this time under pressure from the British and Irish governments. The resulting Stormont House Agreement (SHA) reaffirmed the Haass/O'Sullivan approach and again the parties seemingly agreed much of the substance of the proposals surrounding dealing with the past but strongly disputed the deal's welfare components (McGrattan, 2015). The SHA states that any initiative to deal with the 
past should promote reconciliation, uphold the rule of law, facilitate justice and information recovery, acknowledge and address the suffering of victims and survivors, be human rights compliant and be based on the principles of balance, proportionality, transparency, fairness and equity.

\section{Conclusion}

Contributors within this special section explore ways in which these processes occur and assess the ethical implications they entail. Through an emphasis on silence - and, in particular, how legal processes and discursive dynamics can work to mute and marginalize speech and speakers - both papers work not only to reveal the limitations that may proceed from laudable aims such as transparency, fairness and proportionality; but, in so doing, they help to invert the power disparities and marginalizing practices that can arise from those aims.

The key aim of this special section, however, is not simply to account for democratic set-backs; rather we hope to explore the possibilities that memory might play an integrative role in such societies, dampening bloc perceptions of injustice and victimhood, allaying sectarian attitudes, and promoting an inclusive political culture. These articles address, in diverse ways, to what extent the promotion of inclusive political cultures is a feasible hope of any post-conflict reckoning with the past. We can ask what a 'successful' reckoning might look like: one answer would be a cleareyed recognition of the ongoing silences or 'gaps' in the dominant historical narratives that are continually being produced and adorned. For example, Little and 
McMillan argue that the selective narration of the past relationship between indigenous and non-indigenous peoples in Australia has effectively been used to insulate those groups in power in the present. Graff-McRae, meanwhile, maps the 'gendered ghosts' that continue to haunt the Northern Irish peace process. As such, the objective is to foster interdisciplinary dialogue with a view to extending the theoretical, empirical and policy dimensions of memory studies.

Ideas about peace, justice and reconciliation are often seen as panaceas to these struggles and are given institutional form in structures of governance, truth recovery and transitional justice. The extent to which these institutions enshrine, reproduce or work through traumatic, conflict-ridden pasts seemingly then comes down to a matter of temporal perspective - whether or not in the long-run they can help mend the social fabric. Yet, as Paul Gready (2011) points out, if we do not know what success (peace, truth, justice, reconciliation) actually looks like, how can we evaluate or know if we are on the right tracks. A complementary point can be found in the work of de Brito et al (2001: p. 17), who point out that it is in precisely those countries with the weakest democratic traditions where we find the greatest need for strong democratizing processes. They go on to argue that '[r]ather than talk about reconciliation, it is more appropriate to ask whether accountability processes can contribute to affirming democratic governance' (p.27). 
We suggest, therefore, that post-conflict, deeply-divided societies present 'difficult cases' for the integrative potential of memory, but that that potential may be located within research questions such as

- To what extent is memory necessarily adversarial and contentious?

- Are non-conflictual forms of memory possible? What might they look like?

- Can memory be reconciled with notions of forgiveness, shared responsibility for the past, and reconciliation itself?

- What are the empirical impediments to integrative memory?

- To what extent can we evaluate policy success or failure in this area?

Contributors to this special section tackle these issues and questions by filtering them through the lens of societies marked by deep cleavages.

\section{References}

Abdelal, R., Herrera, Y.M., Johnston, A.I., and McDermott, R. (2006) 'Identity as a Variable', Perspectives on Politics, 4(4), pp. 695-711. 
Assmann, A. and Shortt, L. (2011), 'Memory and Political Change: Introduction', in Assmann, A. and Shortt, L. (eds.) Memory and Political Change. Basingstoke: Palgrave Macmillan.

Marc Augé, M. (2004), Oblivion, translated by Marjolijn de Jager. London: University of Minnesota Press.

Bell, D.S.A. (2003), 'Mythscapes: memory, mythology, and national identity', British Journal of Sociology, 54 (1), pp. 63-81.

Cairns, E. and Roe, M.D. (2003), 'Introduction: Why Memories in Conflict?' in The Role of Memory in Ethnic Conflict, edited by Cairns, E. and Roe, M.D. Basingstoke: Palgrave Macmillan.

Chandra, K. (2006), 'What is Ethnic Identity and Does it Matter?', Annual Review of Political Science, 9, pp. 397-424.

Connerton, P. (1992) How Societies Remember. Cambridge: Cambridge University Press. 
Cubbit, G. (2007) History and Memory. Manchester: Manchester University Press.

de Brito, A., Aguilar, P. and González-Enríquez , C. (2001) 'Introduction', in The Politics of Memory: Transitional Justice in Democratizing Societies, edited by de Brito, A., Aguilar, P. and González-Enríquez, C. Oxford: Oxford University Press.

Decade of Centenaries (N.D.), 'Initial statement by advisory group on centenary commemorations'. Available at http://www.decadeofcentenaries.com/initialstatement-by-advisory-group-on-centenary-commemorations/; accessed on 30 March 2016.

Derrida, J., (1994), Specters of Marx: The State of the Debt, the Work of Mourning \& the New International, trans. Peggy Kamuf. London: Routledge.

Encarnación, O.G. (2014), Democracy without Justice in Spain: The Politics of Forgetting. Philadelphia, PA.: University of Pennsylvania Press.

Freeden, M. (1996), Ideologies and Political Theory: A Conceptual Approach. Oxford: Clarendon Press. 
Gillis, G.R. (1994), 'Memory and Identity: The History of a Relationship' in Commemorations: The Politics of National Identity, edited by J.R. Gillis. Princeton: Princeton University Press.

Graff-McRae, R. (2010), Remembering and Forgetting 1916: Commemoration and Conflict in Post-Peace Process Ireland. Dublin: Irish Academic Press.

Gready, P. (2011) The Era of Transitional Justice: The Aftermath of the Truth and Reconciliation Commission in South Africa and Beyond. Abingdon: Routledge.

Hopkins, S. (2014), 'The Chronicles of Long Kesh: Provisional Irish Republican Memoirs and the Contested Memory of the Hunger Strikes', Memory Studies, 7:4, pp. 425-39.

Hopkins, S. (2015), 'Sinn Féin, the Past and Political Strategy: The Provisional Irish Republican Movement and the Politics of "Reconciliation"”, Irish Political Studies, 30:1, pp. 79-97.

Hopkins, S. (2016), ““Our Whole History has been Ruined!” The 1981 Hunger Strike and the Politics of Republican Commemoration and Memory', Irish Political Studies, $31: 1$, pp. 44-62. 
Jansen, S. 'The Violence of Memories: Local Narratives of the Past after Ethnic Cleansing in Croatia', Local History, 6:1, pp. 77-94

Jelin, E. (2003) State Repression and the Struggles for Memory. London: Latin American Bureau.

Judt, T. (2005), Postwar: A History of Europe since 1945. London: William Heinemann.

Kubal, T. (2008), Culture Movements and Collective Memory: Christopher Columbus and the Rewriting of the National Origin Myth. Basingstoke: Palgrave Macmillan.

McCaffrey, S. (2015), 'Demographic shifts force change on NI politicians', Irish Times, $27 \quad$ April 2015. Available at http://www.irishtimes.com/news/politics/demographic-shifts-force-change-on-nipoliticians-1.2190041; accessed on 30 March 2016.

McGrattan, C. (2012), Memory, Politics and Identity: Haunted by History. Basingstoke: Palgrave Macmillan. 
McGrattan, C. (2015), 'The Stormont House Agreement and the New Politics of Storytelling in Northern Ireland', Parliamentary Affairs, i-First publication, doi:10.1093/pa/gsv065.

McGrattan, C. (2016), 'Ideology, Reconciliation and Nationalism in Northern Ireland', Journal of Political Ideologies, 21 (1), pp.61-77.

McIntyre, A. (2008) Good Friday: The Death of Irish Republicanism. New York: Ausubo Press.

Murray, G. and Tonge, J. (2005), Sinn Féin and the SDLP: From Alienation to Participation. London: C Hurst.

Newsletter (2016), 'Unionists standing firm in refusal to attend 1916 celebrations', 21 March 2016. Available at http://www.newsletter.co.uk/news/northern-irelandnews/unionists-standing-firm-in-refusal-to-attend-1916-celebration-events-17287234\#ixzz44NkH0cH1; accessed on 30 March 2016.

O'Rawe, R. (2005) Blanketmen: An Untold Story of the H-Block Hunger Strike. Dublin: New Island. 
O'Rawe, R. (2010) Afterlives: The Hunger Strike and the Secret Offer that Changed Irish History. Dublin: Lilliput Press.

Obradović-Wochnik, J. (2013), "The "Silent Dilemma" of Transitional Justice: Silencing and Coming to Terms with the Past in Serbia', International Journal of Transitional Justice, 7(2), pp. 328-347.

Patterson, H. (2007), Ireland Since 1939: The Persistence of Conflict. London: Penguin.

Ricoeur, P. (1999), 'Memory and Forgetting', in Questioning Ethics: Contemporary Debates in Philosophy, edited by Kearney, R., and Dooley, M. London: Routledge.

Rieff, D. (2011), Against Remembering and Other Essays. Dublin: The Liffey Press.

Schudson, M. (1989), 'The Present in the Past versus the Past in the Present', Communication, 11, pp. 105-113.

Smith, A.D. (1991), National Identity. Harmondsworth: Penguin. 
Stern, S.J. (2004), Remembering Pinochet's Chile: On the Eve of London, 1998. London: Duke University Press.

Tonge, J., Braniff, M., Hennessey, T., McAuley, J.W. and Whiting, S.A. (2015), The DUP: From Protest to Power. Oxford: Oxford University Press.

Weber, M. (1919), 'Politics as a vocation'. Available at http://anthroposlab.net/wp/wp-content/uploads/2011/12/Weber-Politics-as-a-Vocation.pdf, access on 26 February 2016.

${ }^{1}$ The Northern Irish demographics have narrowed from 33 percent Catholic and 67 percent Protestant in the first census of 1926 to 45 percent Catholic and 48 percent Protestant in the last census of 2011; see McCaffrey, 2015. 